\title{
An in vitro Evaluation of Apigenin and Apigenin-7-O-glucoside Against HeLa Human Cervical Cancer Cell Line
}

\author{
DALIANA MINDA ${ }^{1}$, STEFANA AVRAM ${ }^{1}$, IOANA ZINUCA PAVEL ${ }^{1}$, BRIGITTA KIS ${ }^{1}$, \\ ALEXANDRA GHITU ${ }^{1 *}$, ISTVAN ZUPKO ${ }^{2}$, CRISTINA DEHELEAN ${ }^{3}$, VALENTINA BUDA ${ }^{4}$, \\ ZORITA DIACONEASA ${ }^{5}$, ALEXANDRA SCURTU ${ }^{6}$, ALEXA VLAD ${ }^{7}$, CORINA DANCIU ${ }^{1}$ \\ ${ }^{1}$ Victor Babes University of Medicine and Pharmacy, Department of Pharmacognosy, 2 Eftimie Murgu Sq., 300041, Timisoara, \\ Romania \\ ${ }^{2}$ Department of Pharmacodynamics and Biopharmacy, University of Szeged, Eotvos u. 6, Szeged H-6720, Hungary \\ ${ }^{3}$ Victor Babes University of Medicine and Pharmacy, Department of Toxicology, 2 Eftimie Murgu Sq., 300041, Timisoara, \\ Romania \\ ${ }^{4}$ University of Agricultural Sciences and Veterinary Medicine of Cluj-Napoca, Department of Food Science, 3-5 Calea \\ Manastur, 400372, Cluj-Napoca, Romania \\ ${ }^{5}$ Victor Babes University of Medicine and Pharmacy, Department of Pharmacology, 2 Eftimie Murgu Sq., 300041 Timisoara, \\ Romania \\ ${ }^{6}$ Victor Babes University of Medicine and Pharmacy, Department of Pharmacognosy, 2 Eftimie Murgu Sq., 300041 Timisoara, \\ Romania
}

\begin{abstract}
Apigenin (API) is a phytocompound belonging to the subclass of flavones that can be found in both functional foods as well as medicinal plants. Recent studies have assigned API antioxidant, anti-inflammatory, antispasmodic, anti-viral, anti-thrombotic, anti-angiogenic and chemopreventive potential in vitro on various cell lines and/or in experimental animal models. Apigenin-7-O-glucoside (API-7) is one of its main glycosides and can be commonly found in chamomile flowers, parsley, celery. The aim of this study was to evaluate the in vitro antiproliferative and pro-apoptotic effects of API and its glycoside (apigenin-7-O-glucoside) against HeLa human cervical cancer cells. Results have shown that in the set experimental conditions both the aglycone as well as the heteroside elicit antiproliferative and pro-apoptotic potential against the screened cell line, the aglycone being more active than the heteroside.
\end{abstract}

Keywords: apigenin, apigenin-7-O-glucoside, HeLa cells, proliferation, apoptosis

During history natural products from medicinal plants have played a very important role in protection of human health. The latest studies on this field have exhaustively demonstrated that an impressive number of representatives of Plant Kingdom have therapeutically valuable metabolites; hence, natural products obtain extensive importance to be used for medicinal purposes [1, 2]. In the latest years renewed interest in drugs of natural origins can be clearly observed. The qualities that recommend such an approach relief on some main advantages compared to chemically synthesized molecules that include easy availability and low toxicity at recommended therapeutic doses. Moreover, the easy availability and the fact that plant extracts contain different types of phytochemicals which can act by synergy in order to prevent or cure human disease are other arguments that come to support this kind of approach [3].

Flavonoids (2-phenyl-1, 4-benzopyrone) $\left(\mathrm{C}_{15} \mathrm{H}_{10} \mathrm{O}_{5}\right.$ ) have a fifteen carbon skeleton chemical structure which contain two phenyl rings and a heterocyclic ring. Flavonoids can be classified into six subclasses based on their structural complexity: flavones (artichockes, oranges, lime, grapefruit); flavan-3-ols (goji berries, cranberries, red onion, radish, buckwheat); flavanols (apple, peach, pecan nuits, black berries, dark chocolate); anthocyanins (raspberries, strawberries, black currant, red cabbage); flavanones (red grapes, chicory,green pepper,lemons); and isoflavones (soybean) [4]. Flavonoids are widely distributed in many medicinal plants like buckwheat, Japanese acacia, celery, parsley, chamomile, common hawthorn, ginkgo biloba, soybean, corn, silver birch [5,6]. API, chemically know as 4', 5, 7-trihydroxyflavone, belongs to the flavone subclass of flavonoids. It is the aglycone of some naturally occurring glycosides like apigetrin (API-7), vitexin (apigenin7-C-glucoside) and isovitexin (apigenin-6-C-glucosid). Apigetrin, also known as cosmosiin is a natural phytocompounds with better solubility compared to API [7]. API and cosmosiin can be found in many kinds of fruits, vegetables and nutraceuticals, like Apium graveolens L., Pimpinella anisum L., Chrysanthemum morifolium L., Origanum vulgare L., Matricaria chamomilla L., Mentha citrate L., some Rosa L. species.

*email: ghitu.alexandra@gmail.com 
There are numerous research evidences that API and its main glycoside, apigetrin have similar biological activities, the main differences being the intensity of the biological effects [8]. API has been shown to have strong therapeutic potential against a significant number of diseases [9]. Studies in the field have assigned API antioxidant, anti-inflammatory, antispasmodic, anti-viral, anti-thrombotic, anti-angiogenic potential [10]. Different doses of API reduced oxidative damage, neuro-inflammation and microglial activation, events that led to neuroprotective role in Parkinson disease [11]. The flavone is a potent competitive inhibitor of CYP2C9 an enzyme responsible for metabolism of many pharmaceutical drugs in the body [12]. Studies on the topic have shown that apigetrin the conjugated form of API, has remarkable anti-spasmodic, anticarcinogenic, antioxidant, anti-inflammatory, and anti-carcinogenic properties [13].

Nowadays, cancer is one of the most frightening diseases, affecting people of all ages. It is caused by abnormal proliferation and differentiation of cells, and is regulated by tumorigenic factors. Anticancer treatments generally use compounds that target rapidly dividing cells. This treatment has a negative side effect because the normal cells like epithelial cells in the digestive system or the hair follicles are also affected [14]. There is a growing interest in developing natural compounds for cancer therapy. API and API-7 play an important role in cancer prevention by inducing proliferation and apoptosis in various cancer cell lines. Literature describes both studies that have determinates API potential in in vitro cell cultures, whereas others in in vivo animal models. Experimental animal models employing the fallowing cell lines : breast cancer (MCF-7), colon cancer (Caco-2), lung cancer (B16-BL6 murine melanoma cells), pancreatic cancer (PaCC), melanoma cancer (A375), hepatocellular carcinoma $(H C C)$ were designed in order to evaluate the chemopreventive property of this phytocompound [15-19].An increased number of studies assign the cancer preventive effect of API to its antiinflammatory and antioxidant properties [20]. Studies on the topic have shown that in vitro it has antiproliferative and/or pro-apoptotic role against various cancer cell lines including: prostate cancer (PC-3 and DU145), hematologic cancer (HL60), ovarian cancer (HO-8910PM), liver cancer (HeLa), lung cancer B16-BL6 murine melanoma cells) and breast cancer (MCF7). Human trials are only effectuated in the form of supplements [21-23]. In a similar approach a research group have compared API with apigetrin and have found that the glycoside part of apigetrin does not have role in the induction of cell differentiation. In fact, apigetrin inhibited cancer cell growth but to a lower extent than API [24].

The aim of this study was to investigate in vitro the anti-proliferative and pro-apoptotic effects of API and its glycoside (API-7) against HeLa human cervical cancer cells.

\section{Experimental part}

Materials and methods

API and API-7 $\geq 99 \%$ (HPLC) were acquired from Sigma-Aldrich, Germany

\section{Cell culture and preparation}

The HeLa human cervical cancer cell line (ECACC, European Collection of Cell Cultures, Salisbury, UK) was cultured into Dulbecco's Modified Eagle's Medium (DMEM; Gibco BRL, Invitrogen, Carlsbad, CA, USA) supplemented with 10\% heat-inactivated fetal calf serum (FCS; PromoCell, Heidelberg, Germany) and 1\% penicillin/streptomycin mixture (Pen/Strep, 10,000 IU/mL; PromoCell, Heidelberg, Germany). Experiments were conducted when cells were in the nearconfluent phase of growth

\section{Evaluation of the antiproliferative activity}

The growth-inhibitory activity of API and API-7 was tested by standard MTT dye uptake assay on HeLa human cervical cancer cell line as previously described [25]. Briefly HeLa cells were counted and plated at a number of 5000 cells/well into 96-well plates and incubated with the fallowing concentrations of API , respectively API-7: $0.3 \mu \mathrm{M}, 1 \mu \mathrm{M}, 3 \mu \mathrm{M}, 10 \mu \mathrm{M}$, $30 \mu \mathrm{M}$ for $72 \mathrm{~h}$. Afterwards $5 \mathrm{mg} / \mathrm{mL}$ MTT (3-(4,5-dimethylthiazol-2-yl)-2,5-diphenyltetrazolium bromide) solution was added and incubation was performed for another $4 \mathrm{~h}$. Dimethyl sulfoxide was used in order to dissolve the precipitated formazan crystals and the absorbance was spectrophotometrically measured at $545 \mathrm{~nm}$. Wells with untreated cells , respectively dimethyl sulfoxide were utilized as control.

\section{Evaluation of the pro-apoptotoc activity}

For the evaluation of the pro-apoptotic activity API, respectively API-7 on HeLa human cervical cancer cell line, DAPI (4',6-diamidino-2-phenylindole) nucleic acid staining as well as the double Annexin V-FITC staining were performed as previously described $[26,27]$. Based on the evaluation of the antiproliferative activity experiments the chosen concentrations of tested agents were $10 \mu \mathrm{M}$ and $30 \mu \mathrm{M}$. Briley, for DAPI staining HeLa cells were cultured in a 6-well plate and stimulated with the chosen concentrations for $72 \mathrm{~h}$. At the end of this time point cells were washed twice with ice-cold PBS. The next step was fixation in $4 \%$ paraformaldehyde in PBS for a period of $30 \mathrm{~min}$. The fixation was followed by another wash in 
PBS and afterwards permeabilization was induced for 30 min with 2\% Triton X-100 (Sigma Aldrich).Cells were blocked afterwards for one hour with $30 \%$ FCS in $0.01 \%$ Triton X-100. The DAPI staining was realized in the dark for 15 minutes. Visualization of cancer cell nuclei was performed with the help of a fluorescence Olympus IX73 microscope equipped with an integrated DP74 camera (Olympus, Tokyo, Japan).Magnification was 40x. Representative pictures are presented

Translocation of the phosphatidylserine residues of the HeLa human cervical cancer cell line, as well as alteration of cell membrane and nuclei was detected by Annexin V-FITC combined with a propidium iodide (PI) kit (Invitrogen, ThermoFisher, Vienna, Austria).The number of cells employed in this experiment was $10^{6}$ and the staining steps fallowed manufacturer's protocol indications. The cells were analyzed by flow cytometry on FACS Canto II (BD Biosciences, Heidelberg, Germany) using a FACS DIVA device. The experiment was repeated three times. Representative dot-plots are presented.

\section{Results and discussions}

Results show that both API, the aglycone as well as the API-7 heteroside present an important antiproliferative activity against HeLa human cervical cancer cell line. The calculated IC 50 values are $12.08 \mu \mathrm{M}$ for API respectively $18.28 \mu \mathrm{M}$ for API-7. As expected the aglycone is more active than its conjugated form, but the conjugation element,glucose does not significantly influence the antiproliferative activity. At the highest tested concentration, namely $30 \mu \mathrm{M}$ an inhibition of proliferation of $81.91 \pm 0.59$ for API, respectively $63.97 \pm 2.26$ for API-7 could be detected. Results that depict logarithmic dose-response curves employing the fallowing concentrations: $0.3 ; 1 ; 3 ; 10 ; 30 \mu \mathrm{M}$ can be seen in Figure 1 .

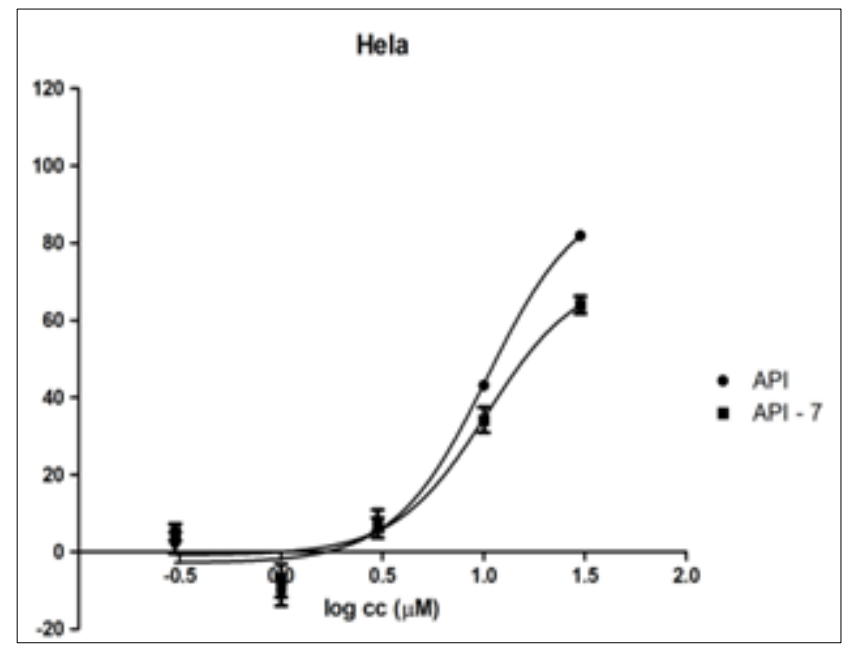

Fig. 1 Antiproliferative activity of API and API-7 against HeLa human cervical cancer cell line

In order to primary evaluate also a possible apoptotic potential as a secondary mechanism for the anti-cancer activity, DAPI staining, a well-known technique that stains cell nuclei in blue was performed. Incubation with this phytocompound led to a reduction in cell number, as it can be seen by decreased number of stained nuclei in a selected field. Also condensed nuclei as a sign of loss of membrane integrity, condensed chromate filaments or nuclear fragmentation fallowing incubation with API, respectively API-7 could be detected. Representative pictures can be seen in Figure 2.

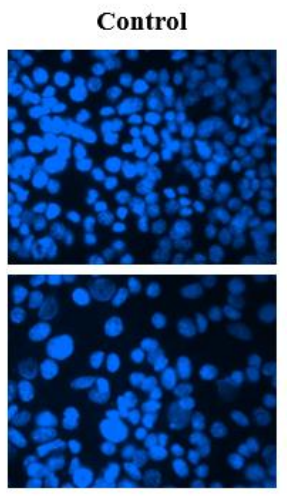

Control
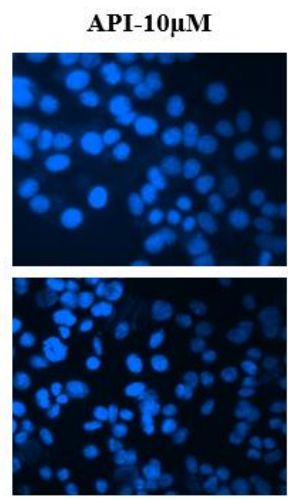

API-7-10 $\mu$ M
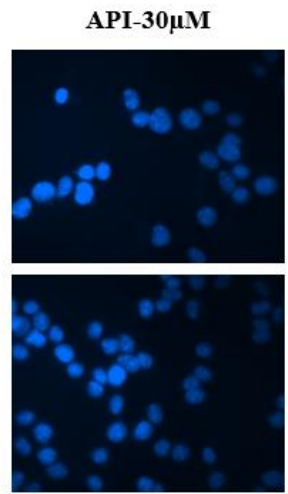

API-7-30 $\mu$ M
Fig. 2 DAPI staining of HeLa human cervical cancer cell line after incubation with API and API-7 
The Annexin V-PI double staining show that HeLa human cervical cancer cells suffer phenomena of early apoptosis, late apoptosis and as well, in a low percentage necrosis. The number of total apoptotic events is linear with the concentration , API being more active than API-7. The most frequent recorded phenomena were the early apoptotic ones. The average value of viable cells fallowing incubation with API $-10 \mu \mathrm{M}$ is $79 \pm 2$; API $-7-10 \mu \mathrm{M}$ is $84 \pm 3$; API -30 is $67.5 \pm 2.5 \mu \mathrm{M}$ and API -7-30 $\mu \mathrm{M}$ is $72.5 \pm 2.5$. Results can be seen in Figure 3 .

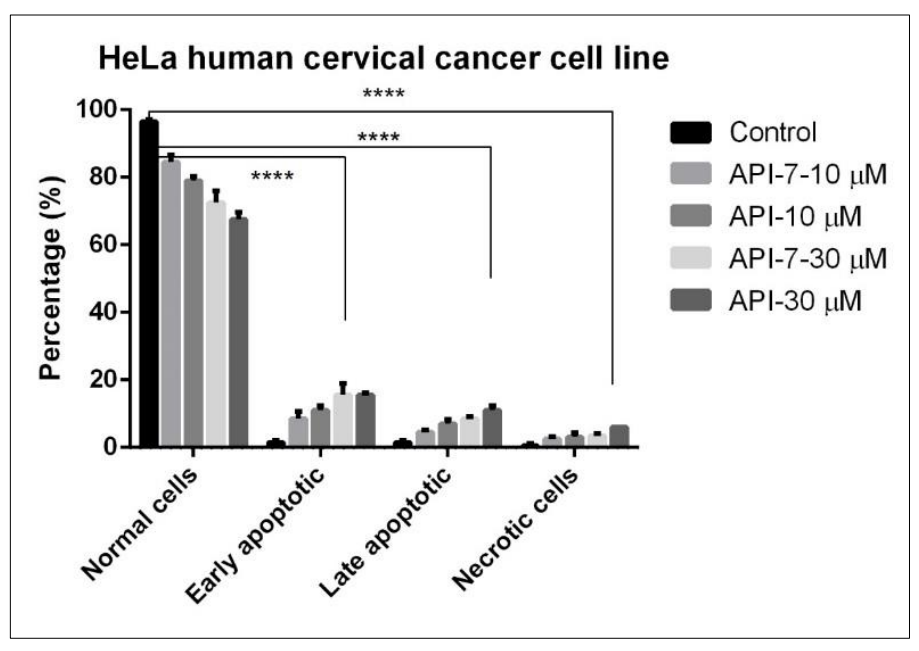

Fig.3 Annexin V-PI staining of HeLa human cervical cancer cell line after incubation with API and API-7

Over time, API has gained much popularity due to low toxicity on normal cells compared to cancer cells, this compound proved to possess chemopreventive and therapeutic potential against some variety of cell lines [28].

Human cervical cancer has two major histologic subtypes: squamous cell carcinoma (SCC) - SiHa and adenocarcinoma (AC) - HeLa. Patients with adenocarcinoma have a worse prognosis than patients with squamous cell carcinoma, requiring a specific therapeutic strategy to the cervical cancer subtype [29].

Our results demonstrated that both API, the aglycone as well as the API-7, the heteroside present a moderate antiproliferative and pro-apoptotic activity against HeLa human cervical cancer cell line but in a different manner, the aglycone being more active than the heteroside.

In a similar research line, Pei-Ming Yang et al. analyzed by the consecrated MTT assay the cytotoxicity of API using the human cervical cancer cell lines HeLa and $\mathrm{SiHa}$ in a dose range of 5-15 $\mu \mathrm{M}$. Thus, in response to the treatment, results have shown that HeLa cells were more sensitive than SiHa cells, concluding that the anticancer effect of API may depend on the subtype of cancer of the cervix. A therapeutic approach that involves the combination of IFN $\gamma$ with API has shown that API has a synergistic effect in combination with IFN $\gamma$. To analyze the combination effect of API and IFN $\gamma$, it was calculated the combination index (CI). The CI values in HeLa cells were lower than 1, thus it was observed that the combination of IFN $\gamma$ with API has diminished the cell viability in HeLa cells [29].

In a related approach the effects of API and API-7 on other cell lines have also been studied.

The group of Haihua Bai et al. evaluated the effects of API on MCF-7 human breast cancer cell lines and MCF-10A human normal mammary cells. Both viability as well as apoptosis had a direct proportional dose-dependent and time relationship with API concentration. $\mathrm{IC}_{50}$ was $109.3 \pm 3.7 \mu \mathrm{mol} / \mathrm{L}$ fallowing $24 \mathrm{~h}$ of incubation and $65.8 \pm 4.3 \mu \mathrm{mol} / \mathrm{L}$ fallowing $24 \mathrm{~h}$ of incubation of MCF-7 cell lines. Results showed that API inhibits the growth of MCF-7 cells dosedependent, but without cytotoxic effects on normal breast cells. Cell apoptosis was determined by Annexin V-FITC-PI double staining. It was observed that $24 \mathrm{~h}$ exposure to $100 \mu \mathrm{mol} / \mathrm{L}$ API induced a significant augmentation of late apoptosic and necrotic events of MCF-7 cells (from 1.6\% to 17.2\%). Decreasing the dose to $80 \mu \mathrm{mol} / \mathrm{L}$, the ratio of early apoptosis in MCF-7 cells changed (from 1.1\% to 18.6\%.). The study concluded that API can induce both apoptosis as well as necrosis in MCF-7 cancer cells [30].

Nouha Nasr Bouzaiene et al. have shown that incubation of B16F10 mouse melanoma cells with apigenin-7-glucoside in the dose range [10-50 $\mu \mathrm{M}$ ] using as time points 24 and $48 \mathrm{~h}$ inhibited cell proliferation in a dose-dependent manner. To explicate the death mechanism of B16F10 cells induced by apigenin-7-glucoside, it was examined whether API-7 can induce apoptosis by observing morphological changes, these being analyzed and quantified by fluorescent microscopy. At the highest concentrations, it was discovered that the percentage of apoptotic cells increased from 5\% (control) to $43 \%$ in case of cells incubated for $48 \mathrm{~h}$ with API-7 [31]. 
In the study designed by Whasun Lim et al., the viability of two types of choriocarcinoma cells (JAR and JEG3) was examined after incubation with API at doses of 0,$5 ; 10 ; 20 ; 50$ and $100 \mu \mathrm{M}$. Between concentrations of [10-100 $\mu \mathrm{M}]$, API reduced survival of JEG3 cells. The populations of apoptotic choriocarcinoma cells were estimated by annexin V and propidium iodide (PI) staining. The percentage of apoptotic JAR and JEG3 cells increased following incubation with 20 $\mu \mathrm{M}$ API with the following percentages: $30 \%$ for JAR cells and 50\% for JEG3 cells [32].

In a similar approach, Shuhua Shan et al. showed a reduction in the survival rate of three colon cancer cell lines (HCT116, HT29 and DLD1) following treatment with API. The $\mathrm{IC}_{50}$ values against HCT116, HT29, and DLD1 cells were 27.9 \pm 2.45 , 48.2 \pm 3.01 and $89.5 \pm 4.89 \mu \mathrm{M}[33]$.

As for an in vivo approach Hui-Hui Cao et al. demonstrated the anti-metastatic effect of API in an animal model of melanoma that involved the injection of B16F10 melanoma cells into syngenic C57BL / 6 mice. Some of these species were treated with API $(150 \mathrm{mg} / \mathrm{kg})$ and others with vehicle $(0.5 \% \mathrm{CMC}-\mathrm{Na}$ solution). The metastatic nodules in case of API treated mice was significantly reduced compared to those treated with vehicle [34].

\section{Conclusions}

In the set experimental conditions, API as well as API-7 presents in vitro antiproliferative and pro-apoptotic potential against HeLa human cervical cancer cell line, the aglycone being more active than the heteroside.

\section{References}

1. SÜNTAR, I., BARRECA, D., FISCHER, N., EFFERTH, T. Phytotherapy Research, 2017, p. 1-14.

2. TIULEA, C., PEEV, C., BREZOVAN, D., DEHELEAN, C., MOTOC, A. Rom J Morphol Embryol, 52, nr.3, 2011 , p. $1065-9$.

3. HAMEDI, A., ZARCHENAS, M. M., SOHRABPOUR, M., ZARGARAN, A. Pharm Biol., 51, nr. 9, 2013, p. $1208-1218$.

4. KOZLOWSKA, A., SZOSTAK-WEGIEREK, D. Rocz Panstw Zakl Hig. 65, nr. 2, 2014, p.79-85.

5. PANCHE, A.N., DIWAN, A.D., CHANDRA, S.R. J Nutr Sci. 5, nr.47, 2017.

6. DANCIU, C., ZUPKO, I., BOR, A., SCHWIEBS, A., RADEKE, H., HANCIANU, M., CIOANCA, O., ALEXA, E., OPREAN, C., BOJIN, F., SOICA, C., PAUNESCU, V., DEHELEAN, C.A. Int Journal of Molecular Sciences, 19, nr.11, 2018, p. 3624.

7. SMILJKOVIC,M., STANISAVLJEVIC, D., STOJKOVIC, D., PETROVICB ,I., VICENTIC, J.M., POPOVIC, J., GRDADOLNIK, S.G., MARKOVIC, D., SANKOVIĆ-BABIĆ ,S., GLAMOCLIJA, J., STEVANOVIC, M., SOKOVIC, M. EXCLI Journal, 16, 2017, p. $795-807$.

8. WANG, Y., XU, Z., HUANG, Y., WEN, X., WU, Y., ZHAO, Y. (n.d.). Molecules, 23, nr.11, 2018.

9. SINGH, P., MISHRA, S. K., NOEL, S., SHARMA, S., RATH, S. K. PLoS One, 7, nr.2, 2012.

10. SKERGET, M., KOTNIK, P., HADOLIN, M., RI, A., SIMONI, M. Food Chemistry, 89, nr.2, 2005, p. 191-198.

11. PATIL, S. P., JAIN, P. D., SANCHETI, J. S., GHUMATKAR, P. J., TAMBE, R., SATHAYE, S. Neuropharmacology, 86, 2014 , p.192-202.

12. SI, D., WANG, Y., ZHOU, Y., GUO, Y., WANG, J., ZHOU, H., FAWCETT, J. P. Drug Metab Dispos, 37, nr.3, 2008.

13. GUZELMERIC, E., VOVK, I., YESILDA, E. J Pharm Biomed Anal, 107, 2014, p.108-18.

14. MADUNIC, J., MADUNIC, I. V., GAJSKI, G., POPIC, J., GARAJ-VRHOVAC, V. Cancer Lett, 413, 2018, p.11-22.

15. PATIL, S. P., JAIN, P. D., SANCHETI, J. S., GHUMATKAR, P. J., TAMBE, R., SATHAYE, S. Neuropharmacology, 86, 2014, p.192-202.

16. AU, A., LI, B., WANG, W., ROY, H., KOEHLER, K., BIRT, D. Nutr Cancer, 54, nr.2, p.243-51.

17. NELSON, N., SZEKERES, K., ICLOZAN, C., RIVERA, I. O., MCGILL, A., JOHNSON, G., GHANSAH, T. PLoS One, 12, nr.2, 2017, p.1-17.

18. KIRALY, A. J., SOLIMAN, E., JENKINS, A., DROSS, R. T.. Prostaglandins Leukot Essent Fatty Acids, 104, 2016 , p.44-53.

19. LI, G., CHI, C. W., SHAO, X. F., FANG, C.H. Biochem Biophys Res Commun, 487, nr.1, 2017, p.122-127.

20. SINGH, P., MISHRA, S.K., NOEL, S., SHARMA, S., RATH, S.K. PLoS One, 7, nr.2, 2012.

21. DAS, S., DAS, J., SAMADDER, A., BOUJEDAINI, N., KHUDA-BUKHSH, A.R. Exp Biol Med, 237, nr.2, 2012, p.1433-1448.

22. HARRISON, M.E., POWER COOMBS, M.R., DELANEY, L.M., HOSKIN, D.W. Exp Mol Pathol, 97, nr.2, 2014 , p. $211-217$.

23. SUH, Y.A., JO, S.Y., LEE, H.Y., LEE, C. Int J Oncol, 46, nr.3, 2015, p.1405-1411.

24. SRIVASTAVA, J.K., GUPTA, S. J Agric Food Chem, 55, nr.23, 2007, p. 9470-9478.

25. DANCIU, C., MUNTEAN, D., ALEXA, E., FARCAS, C., OPREAN, C., ZUPKO, I., BOR, A., MINDA, d., PROKS, m., BUDA, V., HANCIANU, M., CIOANCA, O., SOICA, C., POPESCU, S., DEHELEAN, C.A. Molecules, 24, nr.1, 2018.

26. DANCIU, C., ZUPKO, I., BOR, A., SCHWIEBS, A., RADEKE, H., HANCIANU, M., CIOANCA, O., ALEXA, E., OPREAN, C., BOJIN, F., SOICA, C., PAUNESCU, V., DEHELEAN, C.A. Int J Mol Sci. 19, nr.11, 2018.

27. PFARR, K., DANCIU, C., ARLT, O., NESKE, C., DEHELEAN, C., PFEILSCHIFTER, J.M., RADEKE, H.H. PLoS One. 10, nr. 3 , 2015.

28. SHI, M.D., SHIAO, C.K., LEE, Y.C., SHIH, Y.W. Cancer Cell International . 15, nr. 1, 2015.

29. YANG, P.M., CHOU, C.J., TSENG, S.H., HUNG, C.F. Oncotarget . 8, nr.28, 2017.

30. BAI, H., JIN, H., YANG, F., ZHU, H., CAI, J. Scanning. 36, nr. 6, 2014, p.622-31.

31. NASR BOUZAIENE, N., CHAABANE, F., SASSI, A., CHEKIS-GHEDIRA, L., GHEDIRA, K. Life Sciences, 144, 2016 , p.80-5.

32. LIM, W., PARK, S., BAZER, F.W., SONG, G. J Cell Physiol, 231, nr. 12, 2016, p.2690-9.

33. SHAN, S., SHIh, J., YANG, P., JIA, B., WU, H., ZHANG, X. J Agric Food Chem, 65, nr. 37, 2017, p.8136-44.

34. CAO, H.H., CHU, J.H., KWAN, H.Y., SU, T., YU, H., CHENG, C.Y. Sci Rep , 6, nr. 1, 2016.

$\overline{\text { Manuscript received: } 24.10 .2019}$ 
